\title{
THE EFFECTS OF UNRIPE BANANA FLOUR ON RESISTANT STARCH CONTENT AND QUALITY CHARACTERISTICS OF GLUTEN-FREE RICE COOKIES
}

\author{
PAKKAWAT DETCHEWA*1, PATCHAREE PRASAJAK ${ }^{1}$, WICHIEN SRIWICHAI ${ }^{2}$ AND \\ ANUCHITA MOONGNGARM ${ }^{3}$
}

${ }^{1}$ The Department of Agro-Industry Technology and Management, ${ }^{2}$ The Department of Innovation and Product Development Technology, Faculty of Agro-Industry, King Mongkut's University of Technology North Bangkok, Prachinburi Campus, Thailand. ${ }^{3}$ The Department of Food Technology and Nutrition, Faculty of Technology, Mahasarakham University, Thailand.

*Corresponding author: Pakkawat.d@agro.kmutnb.ac.th

Submitted final draft: 21 September 2020 Accepted: 4 October 2020

http://doi.org/10.46754/jssm.2021.02.008

\begin{abstract}
Rice (Oryza sativa L.) is considered as a gluten-free food. However, using rice flour to prepare cookies has its limitations, such as poor texture and low sensory quality acceptance by consumers. This paper investigates the effects of substituting resistant starch (RS) content with banana flour on the quality of gluten-free rice cookies. Rice cookies were prepared by replacing wheat flour with unripe banana flour at $0 \%$ (control), 50\%, $60 \%, 70 \%, 80 \%$ and $100 \%$. The pasting properties of starch, physical properties of the cookies, texture profile, RS content and sensory evaluation were determined. The results indicated that as the degree of banana flour substitution increased, the peak, final and setback viscosities of blended flour also increased. Rice cookies containing unripe banana flour had lower diameters and spread ratio, but higher hardness than the control. RS content of gluten-free rice cookies ranged from $1.90 \%$ to $8.50 \%$ with the increase in banana flour content, while wheat cookies contained $2.85 \%$ of RS. For the sensory evaluation study, the gluten-free rice cookie with $70 \%$ unripe banana flour received the highest overall score and was comparable to wheat cookies. Partially replacing rice flour with unripe banana flour has the potential to produce gluten-free rice cookies with high RS content.
\end{abstract}

Keywords: gluten-free, rice cookie, wheat cookie, resistant starch, unripe banana flour.

\section{Introduction}

Cookies are one of the most popular bakery products in the world, traditionally produced from soft wheat, which has low protein levels, with a weak gluten network and low hydration properties (Ma \& Baik, 2018). The quality of cookies can be improved by increasing dietary fiber and adding malted wheat and fruit products (Yang et al., 2020). However, gluten in bakery products made from wheat can cause inflammation in the small intestine and reduce the body's ability to absorb nutrients due to Celiac disease or gluten allergy. There is currently no medical treatment for this disease, and a strict gluten-free diet is recommended (Koehler et al., 2014). Rice (Oryza sativa L.), as one of the most important global cereals, is considered to be a gluten-free food. However, using rice flour to prepare cookies has several limitations, such as poor texture, poor color, low sensory quality acceptance by consumers and a high glycemic index.

Unripe banana (Musa sapientum L., Kluai Nam Wa) is a good source of dietary fiber, resistant starch, non-starch polysaccharides, including pectin, and other bioactive compounds (Faisant et al., 1995; Moongngarm et al., 2014; Segundo et al., 2017). Resistant starch (RS) is a bioactive compound that has a high potential to improve dietary fiber and lower the glycemic index in food products. Resistant starch is a complex carbohydrate that resists digestion in the upper gastrointestinal tract. RS is fermented in the colon by microorganisms to produce short-chain fatty acids (SCFAs) that are beneficial for colonic health. Resistant starches are classified into five types as RS1 (physically inaccessible starches), RS2 (granular starches), RS3 (retrogradation starches), RS4 (chemical modified starches) and RS5 (amylose-lipid 
complexes) (Champ, 2004; Brown et al., 2006). Unripe banana flour is also a good source of total phenolic content with $746.67 \mathrm{mg}$ catechol/100 $\mathrm{g}$ flour and $65.58 \%$ antioxidant activity (Haslinda et al., 2009). Unripe banana flour contains resistant starch type 2 (RS2) (Brown et al., 2006) at up to $48.88 \%$ (Moongngarm et al., 2014). Unripe banana flour has been used in a variety of products to increase the RS content and improve digestibility. AgamaAcevedo et al. (2012) reported that the RS content increased from $2.3 \%$ to $8.4 \%$, with $50 \%$ replacement of wheat flour with unripe banana flour in cookie products, while Ratnarari et al. (2018) reported a $14.6 \%$ RS content in wheat cookies substituted with unripe banana flour at $75 \%$. The physicochemical properties of unripe banana flour are different from rice flour and may enhance the quality characteristics of gluten-free rice cookies. However, only a few studies have investigated the effects of replacing rice flour with unripe banana flour in gluten-free rice cookies. Therefore, here, the effects of unripe banana flour substitution in gluten-free rice cookies on pasting properties, physical properties and resistant starch content was investigated. A sensory evaluation was also conducted to compare composite rice and banana flour cookies with wheat flour cookies.

\section{Materials and Methods}

Rice (Oryza sativa L.), indica cultivar Pathum Thani 1, was obtained from the Bureau of Rice Research and Development of Thailand. Wheat flour was purchased from a local supermarket. Bananas (Musa sapientum L., Kluai Nam Wa) were sourced from a farmer in Muang district, Prachinburi, Thailand. All chemical reagents were of analytical grade.

\section{Rice Flour and Banana Flour Preparation}

Rice flour was produced by dry milling. The polished rice was dry-milled using an Alpine Pin Mill (160 Z, Augsburg, Germany). The rice flour was passed through a 100 mesh sieve, packed in plastic bags and stored at $4{ }^{\circ} \mathrm{C}$ until required for use (Detchewa et al., 2016). Unripe banana flour was produced from green bananas at Stage $2-3$, according to the 7-color scale of the banana chart (Dadzie \& Orchard, 1997), and prepared according to Moongngarm et al. (2014). Briefly, unripe banana slices were soaked in $0.5 \%$ citric acid solution for 15 minutes to avoid enzymatic browning and they were dried in an oven (TD024T, Bangkok, Thailand) at $50{ }^{\circ} \mathrm{C}$ until the moisture content was below $10 \%$. The dried unripe banana slices were grounded using a grinder (HR 2115/01, Bangkok, Thailand) and passed through a 100 mesh sieve. The flour was stored in plastic bags and kept in cold storage at $4{ }^{\circ} \mathrm{C}$ until required for use.

\section{Preparation of Cookies}

Formulations used to prepare the experimental cookies are presented in Table 1. The rice cookie formulations were replaced with banana flour at $0 \%, 50 \%, 60 \%, 70 \%, 80 \%$ and $100 \%$. Replacement percentages were selected from a preliminary study. Ingredients were mixed using a mixer (KitchenAid, MI, USA) at a low speed for 20 minutes. Cookie dough was pressed using a cooking machine (Kuhn Rikon, AG, Switzerland) into star shapes. The cookies were then baked in a household oven at $150{ }^{\circ} \mathrm{C}$ for 20 minutes, allowed to cool for $30 \mathrm{~min}$, and stored at room temperature in sealed plastic containers.

\section{Amylose Content Determination}

The amylose contents in rice flour, unripe banana flour, wheat flour and composite flour were determined using the method by Juliano et al. (1981). The determination of the amylose content was carried out using the iodine-based colorimetric method. The absorbance was measured using a UV-visible spectrometer (Biochem Libra S32, UK ) at $620 \mathrm{~nm}$. The amylose content was determined with the standard amylose curve, using an analytical grade potato amylose starch (Sigma-Aldrich, UK). 
Table 1: Formulations of wheat cookies and rice cookies added with unripe banana flour

\begin{tabular}{lccccccc}
\hline \multirow{2}{*}{ Ingredient (gram) } & \multirow{2}{*}{ Control } & \multicolumn{7}{c}{ Rice:Unripe banana flour } \\
\cline { 3 - 8 } & & $\mathbf{1 0 0 : 0}$ & $\mathbf{5 0 : 5 0}$ & $\mathbf{4 0 : 6 0}$ & $\mathbf{3 0 : 7 0}$ & $\mathbf{2 0 : 8 0}$ & $\mathbf{0 : 1 0 0}$ \\
\hline Wheat flour & 500 & 0 & 0 & 0 & 0 & 0 & 0 \\
Rice flour & 0 & 500 & 250 & 200 & 150 & 100 & 0 \\
Unripe banana flour & 0 & 0 & 250 & 300 & 350 & 400 & 500 \\
Salted butter & 240 & 240 & 240 & 240 & 240 & 240 & 240 \\
Egg & 110 & 110 & 110 & 110 & 110 & 110 & 110 \\
Baking powder & 1.3 & 1.3 & 1.3 & 1.3 & 1.3 & 1.3 & 1.3 \\
Butter flavor & 1.5 & 1.5 & 1.5 & 1.5 & 1.5 & 1.5 & 1.5 \\
Sugar & 150 & 150 & 150 & 150 & 150 & 150 & 150 \\
Water & 50 & 50 & 50 & 50 & 50 & 50 & 50 \\
\hline
\end{tabular}

\section{Pasting Properties Determination}

The pasting properties of rice flour, unripe banana flour, wheat flour and composite flour were determined using a Rapid Visco Analyzer (Model 4S, Newport Scientific, Australia). The pasting profile was recorded as pasting temperature, peak viscosity, hot paste viscosity, breakdown, final viscosity, and setback, following Detchewa et al. (2012).

\section{Gluten Content Determination}

The gluten content was determined using a monoclonal R5-antibody-based sandwich enzyme-linked immunosorbent assay (ELISA), wheat/gluten (gliadin) ELISA Kit II (Morinaga Institute of Biological Inc., Japan) (Detchewa et al., (2016).

\section{Resistant Starch Determination}

The resistant starch (RS) was determined according to the AACC method 32-40.01 using the Megazyme Resistant Starch Assay Kit (Megazyme International Ltd., Ireland) as described by Rungrusmee et al. (2020).

\section{Physical Characteristics of Cookies}

Cookie characteristics were determined 24 hours after baking. Ten cookies were measured for diameter (D) and thickness (T) using a caliper and the spread ratio $(\mathrm{D} / \mathrm{T})$ was calculated. The colors of the ten cookies were measured using a Hunter Lab (ColorFlex EZ, VA, USA) according to Yang et al. (2020). Measurements were taken with the $10^{\circ}$ standard observer and D65 standard illuminate, with results expressed following the CIELAB convention.

\section{Textural Characteristics of Cookies}

The textural properties of ten cookies were determined by a fracture test, using a texture analyzer (TA-XT plus; Stable Micros Systems, UK) and a three-point bend rig probe (HDP/3PB) according to the method described by Yang et al. (2020), with minor modifications. The experiment condition was a $20 \mathrm{~mm}$ probe travel distance, trigger force of $5 \mathrm{~g}$ and test speed of $2.0 \mathrm{~mm} / \mathrm{s}$. The hardness of the cookies was calculated as the maximum force $(\mathrm{N})$ required to break the cookie.

\section{Sensory Evaluation}

Organoleptic testing of the cookies was performed by 30 untrained panelists using a 9-point hedonic scale (Chen et al., 2020; Jan et al., 2018; Stone \& Sidel 2004; Curtis 2013). The scale was $1=$ dislike extremely, $2=$ dislike very much, 3=dislike moderately, 4=dislike slightly, $5=$ neither like nor dislike, $6=$ like slightly, $7=$ like moderately, $8=$ like very much and $9=$ like extremely. The panelists evaluated the cookie samples for appearance, color, texture, and overall acceptability.

\section{Statistical Analysis}

A completely randomized design (CRD) was applied for the data analysis of the amylose 
content, gluten content, resistant starch content, and pasting properties. All experiments were performed in triplicates. The color and texture characteristics analyses were donein 8 repetitions. A randomized complete block design (RCBD) was used for sensory evaluation. Results were expressed as mean \pm standard deviation. The analysis of variance (ANOVA) and Duncan's multiple range test (DMRT) were performed using SPPSS version 22 (SPSS Inc., Chicago, IL, USA) to determine the significant differences $(p<0.05)$ among the mean observations.

\section{Results and Discussion}

\section{Amylose Content in Flour}

The quality of a cookie is highly dependent on the amylase content of the flour. The amylose contents of wheat, rice and unripe banana flour were $26.74 \%, 15.91 \%$ and $42.64 \%$, respectively. The composite flour comprised a mixture of rice flour and unripe banana flour at different ratios, with amylose contents ranging from $15.91 \%$ to $42.64 \%$ (Figure 1 ). The amylose content of the composite flour increased with the increasing substitution levels of unripe banana flour since unripe banana flour had a higher amylose content than rice flour (42.64\%). The amylose content affected the texture of the gluten-free rice cookies. Zhong et al. (2018) reported that adding high amylose maize starch in cake mix affected the texture with increased hardness, cohesiveness, chewiness and resilience, and decreased springiness with increasing resistant starch. Moreover, Devi et al. (2019) found that wheat cookies made from high amylose wheat flour were of better quality than when using low amylose wheat flour.

\section{Pasting Properties of Flour}

The pasting profiles of starches from different sources were significantly different (Table 2). Banana flour showed higher peak viscosity, hot paste viscosity, cold paste viscosity, and setback than rice flour and wheat flour, whereas wheat flour had the highest pasting temperature. Gluten protein in wheat flour acts as a water binding agent and binds with wheat starch, resulting in high pasting temperature (Ghiasi et al., 1993). The effect of unripe banana flour on the pasting properties of rice flour is shown in Table 2. The addition of unripe banana flour increased peak viscosity, hot paste viscosity, final viscosity and setback viscosity. The setback viscosity indicates amylose re-association or retrogradation of starch after cooking, and has been correlated with the texture of various products (Huang et al., 2018). The addition of unripe banana flour increased the setback from 1,619 to $1,885 \mathrm{cP}$. A high setback value of starch promoted good cookie quality (Devi et al., 2019).

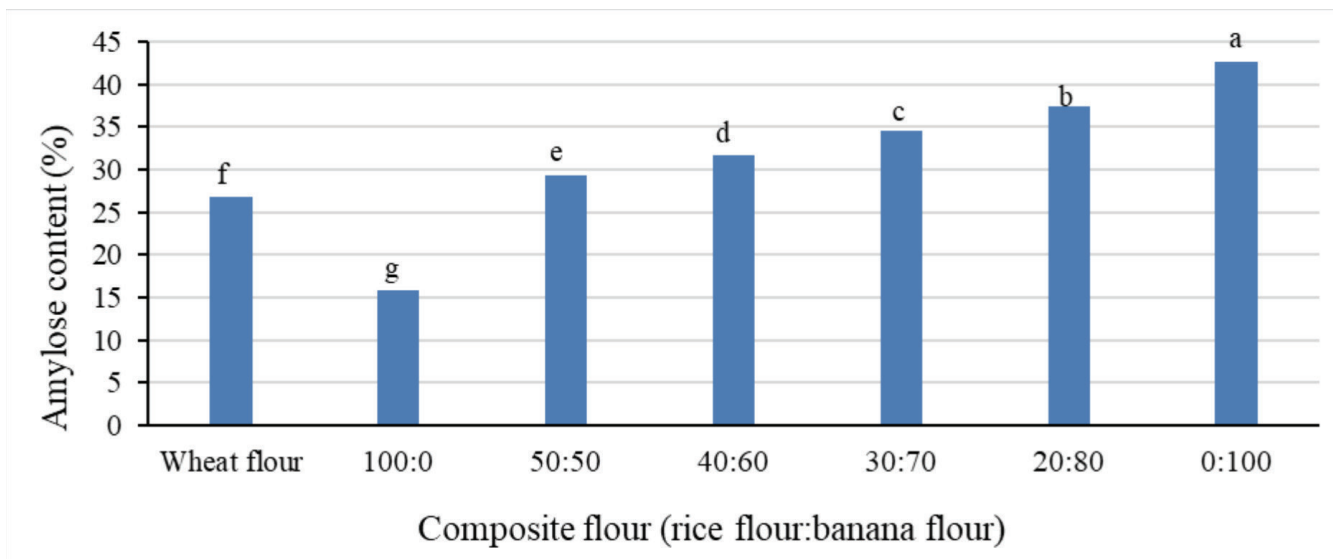

Figure 1: Amylose content in wheat, rice, banana and composite flour mixtures. Graphs with the different letters are significantly different $(\mathrm{p}<0.05)$ 
Table 2: Pasting properties of wheat, rice, unripe banana and composite flour mixtures

\begin{tabular}{cccccccc}
\hline \multicolumn{7}{c}{ Pasting Properties } \\
\hline Sample & $\begin{array}{c}\text { Pasting Temp } \\
\left({ }^{\circ} \mathrm{C}\right)\end{array}$ & $\begin{array}{c}\text { Peak Time } \\
(\mathrm{min})\end{array}$ & $\begin{array}{c}\text { Peak viscosity } \\
(\mathrm{cp})\end{array}$ & $\begin{array}{c}\text { Hot paste } \\
\text { viscosity }(\mathrm{cp})\end{array}$ & $\begin{array}{c}\text { Breakdown } \\
(\mathrm{cp})\end{array}$ & $\begin{array}{c}\text { Final Viscosity } \\
(\mathrm{cp})\end{array}$ & Setback (cp) \\
\hline Wheat flour & $85.43 \pm 0.89^{\mathrm{a}}$ & $6.05 \pm 0.05^{\mathrm{a}}$ & $1911.67 \pm 18.58^{\mathrm{d}}$ & $1309.33 \pm 66.58^{\mathrm{e}}$ & $602.33 \pm 22.68^{\mathrm{c}}$ & $2474.67 \pm 85.82^{\mathrm{e}}$ & $1165.33 \pm 21.78^{\mathrm{d}}$ \\
\multicolumn{1}{l}{ Rice flour: Unripe banana flour } & & & & & & & \\
100:0 (0\%) & $81.38 \pm 0.66^{\mathrm{b}}$ & $5.57 \pm 0.05^{\mathrm{b}}$ & $3510.50 \pm 10.00^{\mathrm{c}}$ & $2041.50 \pm 21.92^{\mathrm{d}}$ & $1469.00 \pm 48.08^{\mathrm{a}}$ & $3660.50 \pm 9.20^{\mathrm{d}}$ & $1619.00 \pm 31.11^{\mathrm{c}}$ \\
$50: 50(50 \%)$ & $79.42 \pm 0.42^{\mathrm{c}}$ & $5.04 \pm 0.08^{\mathrm{c}}$ & $3821.66 \pm 28.74^{\mathrm{bc}}$ & $2347.33 \pm 64.36^{\mathrm{c}}$ & $1474.33 \pm 75.39^{\mathrm{a}}$ & $4090.00 \pm 10.58^{\mathrm{c}}$ & $1742.66 \pm 76.56^{\mathrm{b}}$ \\
$40: 60(60 \%)$ & $79.85 \pm 0.48^{\mathrm{c}}$ & $5.02 \pm 0.10^{\mathrm{c}}$ & $3847.33 \pm 34.02^{\mathrm{bc}}$ & $2631.66 \pm 65.65^{\mathrm{b}}$ & $1399.50 \pm 85.22^{\mathrm{b}}$ & $4392.67 \pm 62.03^{\mathrm{b}}$ & $1761.00 \pm 96.70^{\mathrm{b}}$ \\
$30: 70(70 \%)$ & $79.95 \pm 0.07^{\mathrm{c}}$ & $4.97 \pm 0.05^{\mathrm{c}}$ & $4008.50 \pm 34.76^{\mathrm{b}}$ & $2609.00 \pm 25.77^{\mathrm{b}}$ & $1215.66 \pm 28.99^{\mathrm{b}}$ & $4466.00 \pm 33.65^{\mathrm{b}}$ & $1857.00 \pm 67.88^{\mathrm{a}}$ \\
$20: 80(80 \%)$ & $79.55 \pm 0.07^{\mathrm{c}}$ & $4.97 \pm 0.05^{\mathrm{c}}$ & $4101.50 \pm 24.15^{\mathrm{b}}$ & $2789.00 \pm 22.33^{\mathrm{b}}$ & $1219.50 \pm 31.82^{\mathrm{b}}$ & $4653.00 \pm 57.98^{\mathrm{b}}$ & $1864.00 \pm 5.66^{\mathrm{a}}$ \\
$0: 100(100 \%)$ & $79.00 \pm 0.00^{\mathrm{c}}$ & $4.54 \pm 0.05^{\mathrm{c}}$ & $4249.00 \pm 26.27^{\mathrm{a}}$ & $3010.10 \pm 13.84^{\mathrm{a}}$ & $1239.50 \pm 12.43^{\mathrm{b}}$ & $4895.50 \pm 72.83^{\mathrm{a}}$ & $1885.00 \pm 41.01^{\mathrm{a}}$ \\
\hline
\end{tabular}

Values are means \pm standard deviation. Mean values for each characteristic followed by different letters within the same column are significantly different $(\mathrm{p}<0.05)$

\section{Gluten Content}

The gluten content was determined using a monoclonal R5-antibody-based sandwich enzyme-linked immunosorbent assay (ELISA). Rice flour, unripe banana flour and composite flour cookies contained less than 1 ppm of gluten, but wheat cookies contained 153,510 ppm. Gluten-free rice cookies with unripe banana flour replacement at $0 \%$ to $100 \%$ contained gluten below $1 \mathrm{ppm}$. Thus, these cookies were gluten-free according to the US Food and Drug Administration (2019) guidelines that state gluten-free food as food containing less than $20 \mathrm{ppm}$ of gluten.

\section{Physical Characteristics of Cookies}

The moisture content and water activity $\left(\mathrm{a}_{\mathrm{w}}\right)$ play vital roles in cookie products and they have an effect on microbiology activity, texture, sensory evaluation and shelf life (Carter et al., 2015). Moisture content, water activity and the color of cookies are shown in Table 3. The moisture content of gluten-free rice cookies was $2.13 \%$. The substitution of unripe banana flour from $50 \%$ to $100 \%$ of rice flour resulted in an increase in the moisture content (2.92 to $3.36 \%$ ) of cookies. Nevertheless, the moisture contents of glutenfree rice cookies with unripe banana flour and wheat cookies (3.34\% moisture content) were not significantly different $(\mathrm{p}<0.05)$. Adding unripe banana flour to rice flour from $0 \%$ to $100 \%$ $\mathrm{w} / \mathrm{w}$ increased $\mathrm{a}_{\mathrm{w}}$ of the cookies from $0.22 \%$ to $0.29 \%$, whereas the $\mathrm{a}_{\mathrm{w}}$ of wheat cookies was $0.28 \%$. Alivola \& Monterde (2018) reported that unripe banana flour had a high water absorption capacity $(1.82 \mathrm{~mL} / \mathrm{g})$, while rice flour and wheat flour had a water absorption capacity of 1.56 and $1.31 \mathrm{~mL} / \mathrm{g}$, respectively. Thus, unripe banana flour could absorb and bind water more than rice and wheat flour, which resulted in rice cookies containing unripe banana flour having higher levels of $\mathrm{a}_{\mathrm{w}}$ and moisture content compared with rice cookies without unripe banana flour.

According to Katz and Labuza, (1981), the moisture content of cookies should not ne higher than $9 \%$ and $\mathrm{a}_{\mathrm{w}}$ not higher than 0.35 to keep the quality of the product good. Carter et al. (2015) found that the crispness value of cookies changed as the water activity value changed. Cookies were softer at high moisture content and $\mathrm{a}_{\mathrm{w}}$, whereas cookies with low moisture content and low $\mathrm{a}_{\mathrm{w}}$ were crispier. Our results showed that all cookies were crispy due to low moisture content. Moreover, the $\mathrm{a}_{\mathrm{w}}$ values of all cookies were lower than 0.60 , which may result in the prevention of microbial growth and food spoilage (Belitz \& Grosch, 1999).

The color of gluten-free rice cookies with unripe banana flour was significantly different $(\mathrm{p}<0.05)$ compared with wheat cookies. The color parameters of gluten-free 
rice cookies were $\mathrm{L}^{*} 27.00, \mathrm{a}^{*} 7.80$ and $\mathrm{b}^{*}$ 20.96, with a lighter yellow color compared with wheat flour cookies $\left(\mathrm{L}^{*} 23.27, \mathrm{a}^{*}\right.$ 7.39, $b^{*}$ 21.91). The replacement of rice flour with unripe banana flour decreased the lightness (L*) and $\mathrm{a}^{*}$ (redness) and $\mathrm{b}^{*}$ (yellowness) values. The unripe banana flour color is pale. Therefore, when rice flour was replaced with unripe banana flour, the lightness, redness, and yellowness were decreased. The results were similar to the study by Agama-Acevedo et al. (2009), which reported that the increase of banana flour in pastas decreased their lightness.

The dimensions, thickness and spread ratio are important quality parameters of cookies. The spread ratio evaluates the rising ability of cookies; a low spread ratio implies better rising ability (Olapade \& Adeyemo, 2014). The diameter, thickness and spread ratios of wheat and gluten-free rice cookies are shown in Table 4. Gluten-free rice cookies without unripe banana flour had the highest diameter and lowest thickness, with a remarkable increase in spread ratio. The spread ratio of wheat cookies was higher than rice cookies, implying that wheat cookies had better rising ability. Gluten protein in wheat cookies increased the viscosity of the dough (Nugraheni et al., 2017). The addition of unripe banana flour in gluten-free rice cookies reduced the diameter as the substitution level increased from $60 \%$ to $100 \%$, whereas the thickness increased significantly $(p<0.05)$. This decrease in diameter and increase in thickness affected the spread ratio, which implied improved rising ability.

The results of the texture analysis are presented in Figure 2. Hardness is an important factor for sensory evaluation of cookies. Hardness was highest in wheat cookies with a value of $12.05 \mathrm{~N}$, while gluten-free rice cookies ( $0 \%$ unripe banana flour) had the lowest hardness at $5.94 \mathrm{~N}$. The hardness of cookies increased with the increasing amount of unripe banana flour. The texture of gluten-free rice cookies became firmer when unripe banana flour was increased from $50 \%$ to $100 \%$. However, the hardness of gluten-free rice cookies with a replacement of $100 \%$ unripe banana flour was lower than that of wheat cookies. Wheat cookies showed the highest hardness due to the gluten protein in the wheat flour. Gluten-free rice cookies without unripe banana flour had the lowest hardness, but became harder when unripe banana flour was added. The addition of

Table 3: Moisture content, water activity and color of gluten-free cookies

\begin{tabular}{llllll}
\hline & Moisture & Water & \multicolumn{3}{c}{ Color } \\
\cline { 3 - 5 } Cookies & content & activity $\left(a_{w}\right)$ & $L^{*}$ & $a^{*}$ & $b^{*}$ \\
\hline
\end{tabular}

\begin{tabular}{|c|c|c|c|c|}
\hline Wheat flour & $3.34 \pm 0.04^{\mathrm{a}}$ & $0.28 \pm 0.02^{\mathrm{a}}$ & $23.27 \pm 1.43^{b}$ & $7.39 \pm 0.48^{\mathrm{a}}$ \\
\hline
\end{tabular}

Composite flour (rice flour : unripe banana flour)

$\begin{array}{cccccc}100: 0(0 \%) & 2.13 \pm 0.03^{\mathrm{c}} & 0.22 \pm 0.01^{\mathrm{c}} & 27.00 \pm 0.49^{\mathrm{a}} & 7.80 \pm 0.06^{\mathrm{a}} & 20.96 \pm 0.22^{\mathrm{a}} \\ 50: 50(50 \%) & 2.92 \pm 0.04^{\mathrm{b}} & 0.26 \pm 0.01^{\mathrm{b}} & 23.49 \pm 1.35^{\mathrm{b}} & 6.33 \pm 0.28^{\mathrm{bc}} & 14.23 \pm 0.70^{\mathrm{b}} \\ 40: 60(60 \%) & 3.07 \pm 0.04^{\mathrm{b}} & 0.26 \pm 0.01^{\mathrm{b}} & 21.32 \pm 1.32^{\mathrm{b}} & 6.52 \pm 0.18^{\mathrm{b}} & 13.86 \pm 0.45^{\mathrm{b}} \\ 30: 70(70 \%) & 3.14 \pm 0.03^{\mathrm{a}} & 0.29 \pm 0.01^{\mathrm{a}} & 17.82 \pm 0.70^{\mathrm{c}} & 5.94 \pm 0.14^{\mathrm{cd}} & 12.35 \pm 0.50^{\mathrm{b}} \\ 20: 80(80 \%) & 3.21 \pm 0.05^{\mathrm{a}} & 0.28 \pm 0.01^{\mathrm{a}} & 17.74 \pm 1.07^{\mathrm{c}} & 5.64 \pm 0.29^{\mathrm{cd}} & 12.18 \pm 0.57^{\mathrm{bc}} \\ 0: 100(100 \%) & 3.36 \pm 0.06^{\mathrm{a}} & 0.29 \pm 0.02^{\mathrm{a}} & 16.98 \pm 2.79^{\mathrm{c}} & 5.27 \pm 0.91^{\mathrm{d}} & 11.62 \pm 1.01^{\mathrm{c}}\end{array}$

Values are means \pm standard deviation. Mean values for each characteristic followed by different letters within the same column are significantly different $(\mathrm{p}<0.05)$ 
Table 4: Diameter, thickness and spread ratio of cookie samples

\begin{tabular}{lccc}
\hline \multicolumn{1}{c}{ Cookies } & \multicolumn{1}{c}{$\begin{array}{c}\text { Diameter } \\
(\mathbf{c m})\end{array}$} & Thickness (cm) & Spread ratio (D/T) \\
\hline Wheat cookies & $3.24 \pm 0.05^{\mathrm{c}}$ & $0.66 \pm 0.28^{\mathrm{bc}}$ & $4.86 \pm 0.13^{\mathrm{b}}$ \\
Composite flour (rice flour:unripe banana flour) $(\%$ unripe banana flour) & \\
100:0 (0\%) & $3.50 \pm 0.00^{\mathrm{a}}$ & $0.63 \pm 0.06^{\mathrm{c}}$ & $5.55 \pm 0.10^{\mathrm{a}}$ \\
$50: 50(50 \%)$ & $3.47 \pm 0.05^{\mathrm{a}}$ & $0.73 \pm 0.03^{\mathrm{ab}}$ & $4.73 \pm 0.11^{\mathrm{b}}$ \\
$40: 60(60 \%)$ & $3.40 \pm 0.00^{\mathrm{b}}$ & $0.73 \pm 0.06^{\mathrm{ab}}$ & $4.65 \pm 0.20^{\mathrm{b}}$ \\
$30: 70(70 \%)$ & $3.33 \pm 0.05^{\mathrm{c}}$ & $0.75 \pm 0.05^{\mathrm{ab}}$ & $4.44 \pm 0.34^{\mathrm{bc}}$ \\
$20: 80(80 \%)$ & $3.35 \pm 0.05^{\mathrm{c}}$ & $0.77 \pm 0.05^{\mathrm{a}}$ & $4.35 \pm 0.35^{\mathrm{bc}}$ \\
$0: 100(100 \%)$ & $3.30 \pm 0.05^{\mathrm{c}}$ & $0.80 \pm 0.00^{\mathrm{a}}$ & $4.13 \pm 0.00^{\mathrm{c}}$ \\
\hline
\end{tabular}

Values are means \pm standard deviation. Mean values for each characteristic followed by different letters within the same column are significantly different $(\mathrm{p}<0.05)$.

unripe banana flour in rice flour in Figure 1 and Table 2 showed higher amylose contents and setback viscosity, resulting in higher hardness in gluten-free rice cookies with unripe banana flour. The amylose content affected the hardness of the cookie samples, and this may be due to cookies with high amylose content have higher retrogradation, therefore, the cookies with low amylose content showed softer texture. These results were supported by Yu et al. (2009), who reported that the hardness of cooked rice had a positive correlation with amylose contents.

\section{$\operatorname{Hardness}(\mathrm{N})$}

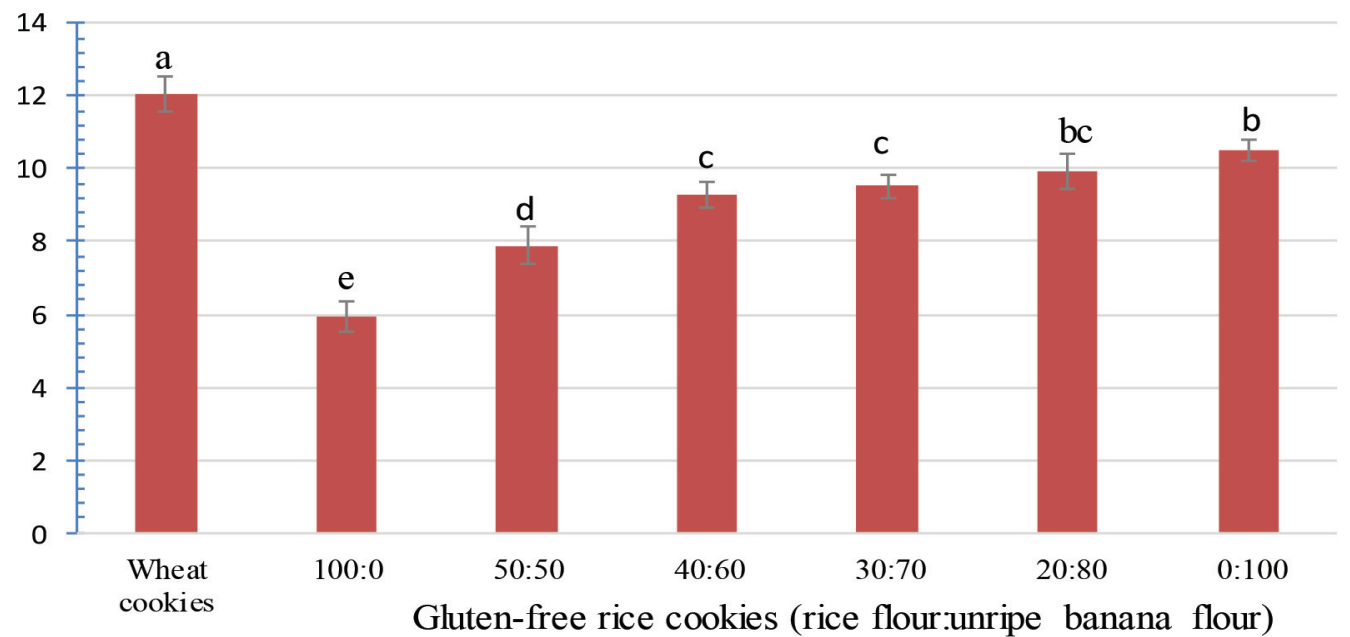

Figure 2: The hardness of wheat cookies and gluten-free rice cookies. Graphs followed by different letters are significantly different $(\mathrm{p}<0.05)$ 


\section{Resistant Starch Content}

The resistant starch contents of gluten-free rice cookies replaced with unripe banana flour at $0 \%$, $50 \%, 60 \%, 70 \%, 80 \%$ and $100 \%$ were $1.92 \%$, $2.70 \%, 3.99 \%, 5.25 \%, 5.77 \%$ and $8.50 \%$, respectively. The increase in resistant starch content is related to the amount of added unripe banana flour, whereas wheat cookies contained a RS content of $2.85 \%$ (Table 5). Gluten-free rice cookies with banana flour showed a higher resistant starch content than gluten-free rice flour ( $0 \%$ unripe banana flour). The highest amount of resistant starch content was found in gluten-free rice flour cookies replaced with $100 \%$ unripe banana flour ( $0 \%$ rice flour). Moongngarm et al. (2014) stated that unripe banana flour had a high RS content (48.88\%), therefore, it was a good source for improving the RS content of food products. Moreover, since unripe banana flour has a high amylose content, baking at high temperature in the presence of free lipids formed amylose-lipid complexes. These results were observed in wheat cookies substituted with 50\% unripe banana flour, containing 8.37\% RS (Agama-Acevedo et al., 2012). Ratnasari et al. (2018) reported that wheat cookies with $75 \%$ unripe banana flour replacement showed increased RS of $14.60 \%$. Moreover, Tiboonbun et al. (2011) reported that rice noodles replaced with banana flour from $0 \%$ to $100 \%$ showed increased resistant starch from $7.49 \%$ to $13.15 \%$. Digestible starch content in rice cookies decreased with the degree of substitution of unripe banana flour to rice flour, ranging between $71.08 \%$ and $73.13 \%$. The total starch content of rice cookies increased with the increased substitution of unripe banana flour to rice flour. A similar result was found in rice noodles with the substitution of unripe banana flour (Tiboonbun et al., 2011).

\section{Surface Appearance}

The surface appearance of the cookie samples is presented in Figure 3. Rice cookies had a lighter color than wheat flour and unripe banana flour cookies. The surface appearance of gluten-free rice cookie with unripe banana flour (Figure $3 \mathrm{~B}$ to $3 \mathrm{G}$ ) were more uneven and less uniform compared with those of wheat cookies (Figure $3 \mathrm{~A})$. These results were due to rice flour and banana flour having no gluten protein to form a strong molecular structure of dough, and, as a result, the cookie surface was uneven. Gluten-free rice cookies replaced with $70 \%$ unripe banana flour (Figure 3E) had a good appearance, while gluten-free rice cookies replaced with $80 \%$ and $100 \%$ unripe banana flour showed a rugged and rough surface, as indicated in Figure 3F and 3G.

Table 5: Resistant starch content in wheat cookies and composite flour cookies

\begin{tabular}{llll}
\hline Sample & Resistant starch (\%) & Digestible starch (\%) & Total starch (\%) \\
\hline Wheat cookies & $2.85 \pm 0.70^{\mathrm{d}}$ & $65.95 \pm 0.25^{\mathrm{d}}$ & $68.8 \pm 0.73^{\mathrm{e}}$ \\
Composite flour (rice flour:unripe banana flour) & & \\
$100: 0(0 \%)$ & $1.92 \pm 0.05^{\mathrm{e}}$ & $73.13 \pm 0.21^{\mathrm{a}}$ & $75.05 \pm 0.14^{\mathrm{d}}$ \\
$50: 50(50 \%)$ & $2.70 \pm 0.10^{\mathrm{d}}$ & $72.55 \pm 0.45^{\mathrm{ab}}$ & $75.25 \pm 0.35^{\mathrm{d}}$ \\
$40: 60(60 \%)$ & $3.99 \pm 0.19^{\mathrm{c}}$ & $71.91 \pm 0.97^{\mathrm{bc}}$ & $75.90 \pm 0.78^{\mathrm{cd}}$ \\
$30: 70(70 \%)$ & $5.25 \pm 0.50^{\mathrm{b}}$ & $71.25 \pm 1.04^{\mathrm{c}}$ & $76.50 \pm 1.03^{\mathrm{bc}}$ \\
$20: 80(80 \%)$ & $5.77 \pm 0.24^{\mathrm{b}}$ & $71.50 \pm 0.50^{\mathrm{c}}$ & $77.28 \pm 0.29^{\mathrm{b}}$ \\
$0: 100(100 \%)$ & $8.50 \pm 0.14^{\mathrm{a}}$ & $71.08 \pm 0.50^{\mathrm{c}}$ & $79.58 \pm 0.16^{\mathrm{a}}$ \\
\hline
\end{tabular}

Values are means \pm standard deviation. Mean values for each characteristic followed by different letters within the same column are significantly different $(\mathrm{p}<0.05)$. 

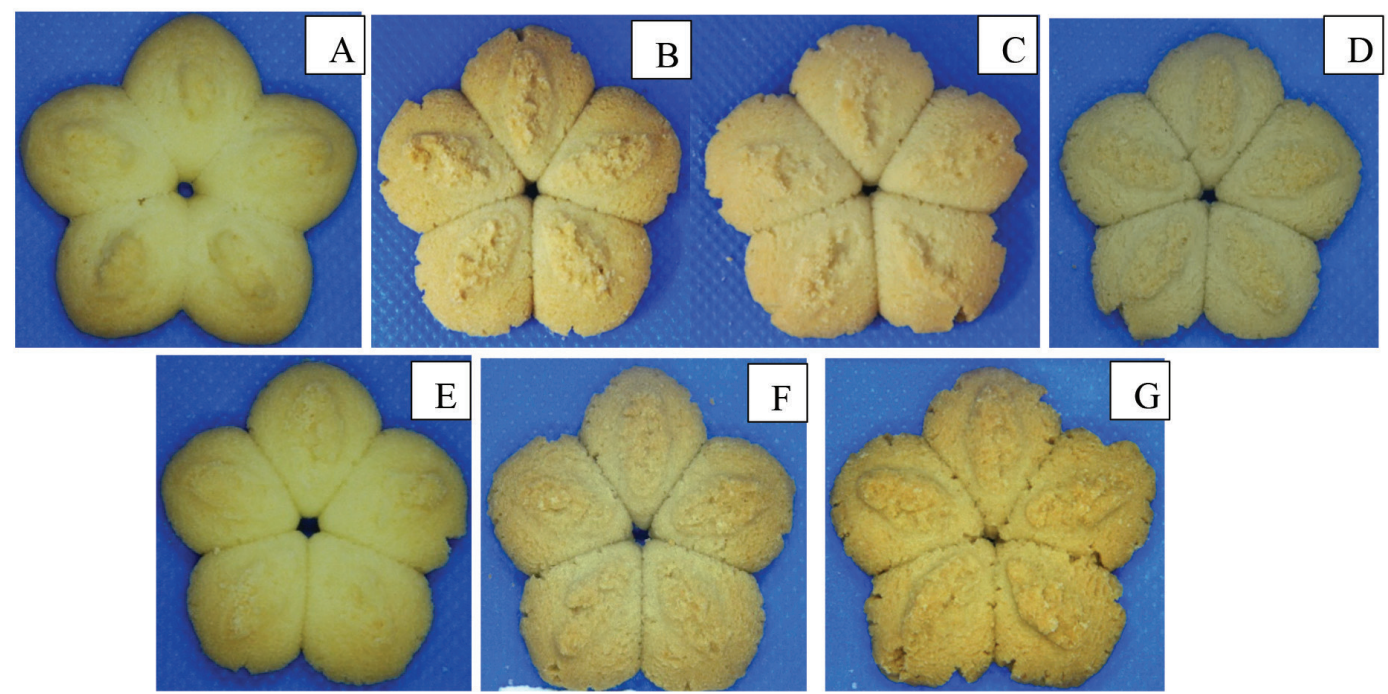

Figure 3: The appearance of wheat cookies (A), gluten-free rice cookies replaced with banana flour at $0 \%$ (B), $50 \%(C), 60 \%(D), 70 \%(E), 80 \%(F)$ and $100 \%(G)$

\section{Sensory Evaluation}

A nine-point hedonic scale was applied to evaluate sensory attributes of the cookies as shown in Table 6. The sensory evaluation assessed appearance, color, texture, flavor, and overall acceptability. The overall acceptability score of gluten-free cookies significantly increased when rice flour was replaced with unripe banana flour at $70 \%$, comparable to the overall acceptability of wheat cookies $(p<0.05)$. At higher levels of addition with unripe banana flour beyond $70 \%$, the overall acceptability scores decreased because the texture of the cookies became hard and the products smelled like raw banana. The results indicated that the sensory attributes of gluten-free cookies prepared with rice flour to unripe banana flour ratio of 30:70 were comparable to that of wheat cookies. Gluten-free rice cookies with unripe banana flour at $80 \%$ and $100 \%$ had low scores for color, texture and overall acceptability. The addition of unripe banana flour at $80 \%$ and $100 \%$ caused a darkening (lower L* value), less reddish (lower a* value), and less yellowish (lower $b^{*}$ value) color. This result concurred with Agama-Acevedo et al. (2009), who reported that an increased percentage of banana flour in pasta formulations decreased lightness.
The substitution of unripe banana flour in rice flour at up to $70 \%$ enhanced the overall acceptability of gluten-free cookies. This result agreed with Roman et al. (2019), who found that using banana starch to make gluten-free bread improved the odor and flavor of the product.

\section{Conclusions}

Unripe banana flour had very high resistant starch content. The results confirmed the feasibility of using unripe banana flour to replace rice flour to produce gluten-free rice-based cookies with improved texture, color and high acceptability that is comparable to wheat flour cookies. The rice flour of gluten-free rice-based cookies can be replaced with unripe banana flour for up to $70 \%$. This result could lead to the development of high resistant starch gluten-free rice cookies as a functional food product. However, further studies regarding the optimization of unripe banana flour and rice flour to maximize the RS content and sensory acceptability, as well as the glycemic index and nutrition quality are needed.

\section{Acknowledgements}

This research was supported by grants funded by the Faculty of Agro-Industry, 
Table 6: Sensory evaluation of wheat cookies and composite flour cookies

\begin{tabular}{lccccc}
\hline \multirow{2}{*}{ Cookies } & \multicolumn{5}{c}{ Sensory attributes } \\
\cline { 2 - 6 } & Appearance & Color & Texture & Flavor & $\begin{array}{c}\text { Overall } \\
\text { acceptability }\end{array}$ \\
\hline Wheat cookies & $8.3 \pm 0.6^{\mathrm{a}}$ & $8.1 \pm 0.5^{\mathrm{a}}$ & $8.1 \pm 0.6^{\mathrm{a}}$ & $8.3 \pm 0.8^{\mathrm{a}}$ & $8.0 \pm 0.5^{\mathrm{a}}$ \\
Composite flour (rice flour:unripe banana flour) & & & \\
100:0 (0\%) & $7.6 \pm 0.5^{\mathrm{ab}}$ & $7.4 \pm 0.6^{\mathrm{a}}$ & $6.4 \pm 0.3^{\mathrm{b}}$ & $6.0 \pm 1.5^{\mathrm{bc}}$ & $6.5 \pm 0.2^{\mathrm{b}}$ \\
$50: 50(50 \%)$ & $7.2 \pm 0.3^{\mathrm{b}}$ & $7.1 \pm 0.2^{\mathrm{ab}}$ & $6.6 \pm 0.4^{\mathrm{b}}$ & $6.4 \pm 0.6^{\mathrm{b}}$ & $6.6 \pm 0.1^{\mathrm{b}}$ \\
$40: 60(60 \%)$ & $7.2 \pm 0.4^{\mathrm{b}}$ & $7.1 \pm 0.3^{\mathrm{ab}}$ & $6.6 \pm 0.3^{\mathrm{b}}$ & $6.9 \pm 0.6^{\mathrm{b}}$ & $6.7 \pm 0.5^{\mathrm{b}}$ \\
$30: 70(70 \%)$ & $7.6 \pm 0.4^{\mathrm{ab}}$ & $7.3 \pm 1.3^{\mathrm{ab}}$ & $7.3 \pm 0.3^{\mathrm{a}}$ & $7.2 \pm 0.3^{\mathrm{a}}$ & $7.8 \pm 0.5^{\mathrm{a}}$ \\
$20: 80(80 \%)$ & $7.4 \pm 0.2^{\mathrm{b}}$ & $6.7 \pm 0.2^{\mathrm{c}}$ & $6.2 \pm 0.4^{\mathrm{b}}$ & $5.9 \pm 0.5^{\mathrm{bc}}$ & $6.1 \pm 0.2^{\mathrm{c}}$ \\
$0: 100$ & $7.00 \pm 0.2^{\mathrm{b}}$ & $6.7 \pm 0.1^{\mathrm{c}}$ & $6.2 \pm 0.3^{\mathrm{b}}$ & $5.5 \pm 0.5^{\mathrm{c}}$ & $5.9 \pm 0.4^{\mathrm{c}}$ \\
\hline
\end{tabular}

Values are means \pm standard deviation. Mean values for each characteristic followed by different letters within the same column are significantly different $(\mathrm{p}<0.05)$

King Mongkut's University of Technology North Bangkok. The authors would like to thank Warittha Deevaja, Gunniga Fuanphol and Jiramon Klinpech for their cooperation.

\section{References}

Alviola, J. N. A., \& Monterde, V. G. (2018). Physicochemical and functional properties of wheat (Triticum aestivum) and selected local flours in the Philippines. Philippine Journal of Science, 147(3), 419-430.

Agama-Acevedo, E., Islas-Hernandez, J. J., Pacheco-Vargas, G., Osorio-Diaz P., \& BelloPerez, L. A. (2012). Starch digestibility and glycemic index of cookies partially substituted with unripe banana flour. $L W T$ Food Science and Technology, 46, 177-182.

Belitz, H. D., \& Grosch, W. (1999). Water. In Belitz, H. D. \& Grosch, W. Food Chemistry (pp.1-7). New York, NY: Springer-Verlag Berlin Heidelberg.

Brown, I. L., Yotsuzuka, M., Birkett, A., \& Henriksson, A. (2006). Prebiotics, symbiotics and resistant starch. Journal of Japanese Association for Dietary Fiber Research, 10, 1-10.
Carter, P. B., Galloway, M. T., Campbell, G. S., \& Carter, A. H. (2015). The critical water activity from dynamic dewpoint isotherms as an indicator of crispness in low moisture cookies. Journal of Food Measurement and Characterization, 9(3), 463-470.

Champ, M. (2004). Resistant starch. In AnnCharlotte, E. Starch in food. New York, NY: Woodhead Publishing.

Chen, G. Hu. R., \& Li, H. (2020). Potassium bicarbonate improves dough and cookie characteristics through influencing physicochemical and conformation properties of wheat gluten. Food Chemistry, X5, 1-7.

Curtis P. C. (2013). Untrained Sensory Panels, In Chris, R. Kerth. The Science of Meat Quality (pp. 215-231). New York, NY: John Wiley \& Sons, Inc.

Dadzie, B. K., \& Orchard, J. E. (1997). Routine post-harvest screening of banana/plantain hybrids: criteria and methods. INIBAP Technical Guidelines2. International Network for improvement of banana and plantain, Montpellier, France, pp. 63.

Detchewa, P., Thongngam, M., \& Naivikul, O. (2012). Physicochemical and thermal 
properties of non-waxy rice flour as affected by waxy rice flour and its influence on textural and cooking properties of rice spaghetti. IPCBEE. 39, 235-239.

Detchewa, P., Thongngam, M., Jane, J. J., \& Naivikul, O. (2016). Preparation of glutenfree rice spaghetti with soy protein isolate using twin-screw extrusion. Journal of Food Science and Technology, 53(9), 34853494.

Devi, A., Sindhu, R., \& Khatkar, B. S. (2019). Morphological, pasting, and textural characterization of starches and their sub fractions of good and poor cookie making wheat varieties. Journal of Food Science and Technology, 56(2), 846-853.

Faisant, N., Buleon, A., Colonna, P., Molis, C., Lartigue, S., Galmiche, J. P., \& Champ, M. (1995). Digestion of raw banana starch in the small intestine of healthy humans: Structural features of resistant starch. British Journal of Nutrition, 73, 111-123.

Ghiasi, K., Hoseney, R. C., \& Varriano-Marston, E. (1993). Effects of flour components and dough ingredients on starch gelatinization. Cereal Chemistry, 60(1), 58-61.

Haslinda, W. H., Cheng, L. H., Chong, L. C., \& Noorazlah, A. A. (2009). Chemical composition and physicochemical properties of green banana (Musa acuminata balbisiana Colla cv. Awak) flour. International Journal of Food Sciences and Nutrition, 60(S4), 232-239.

Huang J., Yang, Q., \& Pu, H. (2018). Slowly digestible starch. In S., Jin (Ed.) Functional Starch and Applications in Food (pp. 2762). Springer Singapore. Springer.

Jan, K. N., Panesar, P. S., \& Singh.S. (2018). Optimization of antioxidant activity, textural and sensory characteristics of gluten-free cookies made from whole indian quinoa flour. LWT, 93, 573-582.

Juliano, B. O., Perez, C. M., Blakeney, A. B, Castillo, D. T., Kongseree, N., Lainelet, B., Lapid, E. T., Murty, V. V. S., Paule, C.
M., \& Webb, B. D. (1981). International cooperative testing on the amylose content of milled rice. Starch/Starke, 33, 157-162.

Katz E. E., \& Labuza, T. P. (1981). Effect of water activity on the sensory crispness and mechanical deformation of snack food products. Journal of Food Science, 46, 403409.

Koehler, P., Wieser, H., \& Konitzer, K. (2014). Chapter 3 - Treatment of Celiac disease. In Oehler, P., Wieser, H., \& Konitzer, K (Eds). Celiac Disease and Gluten (pp.) 149-171. Academic Press, Boston.

Ma, E. Y., \& Baik, B. K. (2018). Soft wheat quality characteristics required for making baking powder biscuit. Journal of Cereal Science, 79, 127-1333.

Moongngarm, A., Tiboonbun, W., Soanpong, M., Sriwong, P., Phiewtong, L., Prakitrum, R., \& Huychan, N. (2014). Resistant starch and bioactive contents of unripe banana flour as influenced by harvesting periods and its application. American Journal of Agricultural and Biological Science, 9(3), 457-465.

Nugraheni, M., Sutopo, Purwanti, S. \& Handayani, T. H. W. (2017). Development of gluten-free cookies rice in resistant starch type 3 from Maranta arundinacea. Pakistan Journal of Nutrition, 16(9), 659665.

Olapade, A. A., \& Adeyemo, M. A. (2014). Evaluation of cookies produced from blends of wheat, cassava and cowpea flours. International Journal of Food Studies, 3, 175-185.

Ratnasari, D., Rustanti, N., Arifan, F., \& Afifah, D. (2018). The effects of treatments on batu banana flour and percentage of wheat substitution on the resistant starch, in vitro starch digestibility content and palatability of cookies made with banana (Musa balisiana Colla) flour. IOP Conference Series: Earth and Environmental Science, $116,1-8$. 
Roman, R., Gomez, M., Hamaker, R., \& Marinez, M. M., (2019). Banana starch and molecular shear fragmentation dramatically increase structurally driven slowly digestible in fully gelatinized bread crumb. Food Chemistry, 274, 664-671.

Rungrusmee S., Shrestha, S., Sadiq, M. B., \& Anal, A. K. (2020). Influence of resistant starch, xanthan gum, inulin and defatted rice bran on the physicochemical, functional and sensory properties of low glycemic gluten-free noodles. LWT-Food Science and Technology, 126, 1-9.

Segundo, C., Roman, L., Gomez, M., \& Martinez, M. M. (2017). Mechaniclally fractionated flour isolated from green bananas ( $M$. cavendishii var. nanica) as a tool to increase the dietary fiber and phytochemical bioactivity of layer and sponge cakes. Food Chemistry, 219, 240248.

Stone, H., \& Sidel, J. L. (2004). Sensory Evaluation Practices. San Diego. CA: Elsevier Academic Press.

Tiboonbun, W., Sungsri-in, M., \& Moongngarm, A. (2011). Effect of replacement of unripe banana flour for rice flour on physical properties and resistant starch content of rice noodle. International Journal of Nutrition and Food Engineering, 5(9), 558561.

US Food and Drug Administration. (2019). Food Labelling: gluten-free labelling for food. Retrieved from https://www.accessdata.fda. gov/scripts/cdrh/cfdocs/cfcfr/CFRSearch. $\mathrm{cfm} ? \mathrm{fr}=101.91$

Yang, B., Guo, M., \& Zhao, Z. (2020). Incorporation of wheat malt into a cookie recipe and its effect on the physicochemical properties of the corresponding dough and cookies. LWT-Food Science and Technology, 117, 1-8.

Yu, S., Ma, Y., \& Sun, D-W. (2009). Impact of amylose content on starch retrogradation and texture of cooked milled rice during storage. Journal of Cereal Science, 50(2), 139-144.

Zhong, Y., Zhu, H., Liang, W., Li, X., Liu, L., Zhang, X., Yue, H., Xue, J., Liu, X., \& Guo, D. (2018). High-amylose starch as a new ingredient to balance nutrition and texture of food. Journal of Cereal Science, 81, 8-14. 